\title{
Clinton's plan for 'green car' faces bumpy research road
}

Washington. The Clinton administration is likely to have considerable difficulty in carrying out a proposed joint 'clean car' research and development programme with the major US car manufacturers.

Diminishing environmental returns from refinements to petrol-driven cars and uncertainty over which alternative power sources to pursue will complicate the plan, according to motor industry experts who last week testified before the clean air and nuclear regulation subcommittee of the Senate Environment and Public Works Committee. In addition, the industry's preference for an inexpensive way to meet tougher environmental regulations leads to different research goals from those of the administration.

There is also concern that too much collaboration between US car makers could blunt their ability to compete in global markets. "If the companies all draw from the same research and technology base, we may inhibit technical and product innovation, just when it is most needed", Albert Sobey, an industry consultant from Michigan, told the subcommittee.

In February, US President Bill Clinton announced his interest in working with the automotive industry on 'clean car' technology. Since then, senior representatives of General Motors, Ford and Chrysler have met several times administration officials led by the president's science adviser, John Gibbons, and Deputy Secretary of Commerce-designate John Rollwagen.

But whereas the administration likes to talk about a greener and more internationally competitive car industry, Detroit wants to spend any available support on overcoming bread-and-butter engineering obstacles in complying with environmental legislation. Laws already passed in California and under consideration in other states would require car makers to reduce each year the hydrocarbon, carbon monoxide and nitrogen oxide emissions of their fleets.

The manufacturers would like to channel any new government money through their existing collaborative research clearing house, the US Council for Automotive Research (USCAR), which coordinates joint research in ten areas, ranging from battery technology to passenger safety. But only one, the Advanced Battery Consortium, has so far attracted significant federal funding, with half of its four-year, \$260-million programme being financed by the Department of Energy. Detroit research managers see the other USCAR consortia as obvious avenues for additional federal support.

Joseph Colucci, an executive director of research at General Motors, says that a consortium founded last summer on low-emissions technology offers the best match between the administration's goals, the capabilities of the federal laboratories and the industry's priorities. "It would be very supportive to have the federal laboratories working on this issue", he says.

The low-emissions consortium deals with technology that will cut petrol engine emis-

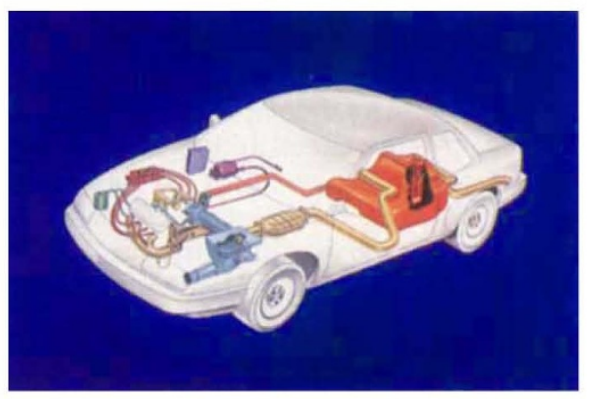

Federal support could help Detroit to develop cleaner emission-control systems.

sions to meet the tightening regulations. Existing catalytic converters can produce extremely low hydrocarbon and carbon monoxide outputs only in optimal conditions. The challenge is to develop converters that will do this at once from a cold start and for the life of the vehicle.

By focusing on this and other problems that USCAR believes are well-suited to collaborative research, the administration would avoid disrupting current plans by Detroit. But it would also miss the chance to coordinate efforts in the most strategically significant areas - such as engine technology which the 'Big Three' have purposely excluded from USCAR.

Gibbons believes that the Department of Energy weapons laboratories can play a significant role in strengthening the US car industry. But in some areas of apparent synergy, such as materials technology, the motor industry's requirements for cheap mass production differ from the military's emphasis on small-volume, high-quality manufacturing in which cost is secondary.

In the meantime, Detroit hopes to get some help in tackling the research problems it faces in dealing with environmental regulation and is counting on better relations with Washington. "In the past, the industry and the government have had an adversarial relationship in this area", says Colucci. "That should change, but it is only what the Japanese have been successfully doing for years."

Colin Macilwain

\section{Research councils want more control of European projects}

Strasbourg. A "club of national research councils, researchers and institutes" to serve European research interests being neglected by the European Communities (EC) has been recommended by participants at a meeting organized last month by France's basic research agency, the CNRS (Centre National de la Recherche Scientifique). They would also like to have an independent body to evaluate European science and special one-year grants to help reintegrate postdoctoral students returning to their country of origin after working elsewhere in Europe.

The recommendations, which reflect concern that the EC is accruing too much power over research, are being presented to France's new research minister, François Fillon. Fillon has pledged to support efforts, particularly those by the CNRS, to increase the control of individual countries over international research collaborations. Widely known for his anti-Maastricht politics, Fillon says that he wants to avoid "getting bogged down at the EC level...whose cumbersome procedures put a damper on the research community".

The proposals are also being presented to national research councils, which have recently discovered that a growing proportion of Europe's research budgets come from the EC's research commission. Meeting for the first time in Bonn in January (see Nature $361,576 ; 1993)$, the councils are trying to make EC-supported international research programmes more efficient and have scheduled a meeting in London in October to discuss the issue.

CNRS was host for the meeting partly because of its desire to take a leading role in Europe's changing research landscape. The agency is trying to decentralize French research by moving half of its laboratories to the regions (see Nature 356, 373; 1992), and taking a bigger role in international research politics would help to fill the vacuum in Paris.

The CNRS has been less successful in setting up an international company called Euroresearch. Under discussion for two years, the company is supposed to allow France, Germany and Spain to administer EC grants to their research institutes and postdoctoral students.

One problem it would address is the proportion of grants - as much as 10 per cent - that are lost to currency conversions because French research institutes cannot hold foreign currencies. But the plan has foundered on the EC's demand for a general liability clause, a feature that has proved difficult to sort out on an international level.

Alison Abbott 